Original Research Paper

\title{
Socio-Economic Community and Marine Resources Status in Supporting Tourist Destination of Small Island in Indonesia
}

\author{
${ }^{1}$ Ma'ruf Kasim, ${ }^{1}$ Dedy Oetama, ${ }^{2}$ Ahmad Bahar, ${ }^{3}$ Mareyke Alelo, \\ ${ }^{4}$ Kartika Kusuma Wardani and ${ }^{4}$ Hertina Susandari \\ ${ }^{I}$ (Faculty of Fisheries and Marine Sciences, Halu Oleo University, Jl. Mokodompit andonohu, Kendari, Southeast Sulawesi, Indonesia \\ ${ }^{2}$ (The Faculty of Marine and Fisheries, Hasanuddin University. Jl. Perintis Kemerdekaan KM. 10 Makassar \\ (Tamalanrea Campus), South Sulawesi, Indonesia \\ ${ }^{3}$ (Manado State Polytechnic, Address: Jl. Raya Polytechnic, Ds. Buha Manado, North Sulawesi, 95252 Manado City, \\ North Sulawesi Province, Indonesia \\ ${ }^{4}$ (Sepuluh Nopember Technology Institute, ITS Sukolilo Campus, Surabaya, Indonesia
}

\author{
Article history \\ Received: 03-07-2021 \\ Revised: 25-08-2021 \\ Accepted: 31-08-2021 \\ Corresponding Author: \\ Ma'ruf Kasim \\ Faculty of Fisheries and Marine \\ Sciences, Halu Oleo \\ University, Jl. Mokodompit \\ andonohu, Kendari, Southeast \\ Sulawesi, Indonesia \\ Email: marufkasim@uho.ac.id
}

\begin{abstract}
Indonesia is one of the countries in the world that has many large islands and thousands of small islands. The small island is a unique environment with a distinctive community life. The main occupations of the people on small islands are generally fishermen and boat owners. This study aims to determine the socio-economic conditions of small islands, especially the livelihoods and incomes of local communities as well as the condition of coastal and shallow marine resources around small islands in supporting the development of marine tourism in one of the small islands in Indonesia. This research was conducted on Barrang Caddi islands, South Sulawesi Province, Indonesia. Data were collected through direct interviews, deep interviews and focus group discussions with local community, local government representatives, traditional leaders and community leaders. Marine resource data is carried out by direct observation and recording in the field. The data collected is analyzed descriptively. During our study, we are found that the main livelihood as fishermen, with an average level of income that is good for their daily life. Besides having a good income, the community also maintains their culture well. Some traditional cultural activities are well developed. This can be an activity that attracts visitors. The findings illustrate those economic conditions with good income are a strong driver in the development of tourist destination in this island. The strength of good tourism is to maintain all the supporting aspect such as cline white sand and marine resources. One of the marine resources that attracts the attention of visitors is coral reefs. Small island communities can increase their income by developing local potential management for marine tourism. Preserving marine resources is a strength that can be developed from marine tourism management. The recommendation of this research is that marine tourism is a prospective social economic development and marine resources strength of the small island.
\end{abstract}

Keywords: Preservation, Tradition and Culture, Eco-Tourism, Infrastructure and Tourism management

\section{Introduction}

Indonesia has many small islands which have enormous potential in tourism development. The development of tourism in small islands is very important by involving the community as a strong driver for its success. The main goal of tourism is to improve the standard of living and community welfare by preserving environmental and socio-cultural activities (Hausler and Strasdas, 2003; Asker et al., 2010; Tasci et al., 2013). Tourism is an important component of the Indonesian economy and generates income for the local people. It involves multiple sectors and has cross-regional characteristics which boost regional development, infrastructure, tourism facilities and the creative industry. Every region or society has a particular culture and tradition 
guarding its people. According to the Ministry of Culture and Tourism Regulation, No KM.67/UM.001/MKP/2004 the active participation of the community is important for development. This process is a well-known involvement pattern (active and passive participation), that needs to be initiated in the preparatory, management and developmental stages. Research conducted at tourism locations in Danang, Vietnam, there are three strategic sectors that influence the success of tourism, including the public sector, the tourism industry and the local community. Within the scope of developing a sustainable tourism destination, it can be seen that very good collaboration is the involvement of local communities and stakeholders, especially in the tourism industry (Nguyen et al., 2018). In Indonesia, one of the potential areas for marine tourism development are archipelagic islands. These groups of small islands have unique characteristics for marine resources such as large coral reefs, beautiful beaches, with the fascinating social and economic conditions (Aspiany et al., 2019). The inhabitants of the archipelago are mostly fishermen, while the serene environment captivates tourists, thereby, boosting their economy. This is referred to as Eco-Tourism and it offers visitors the opportunity to enjoy the true beauty of nature (Valentine, 1993). Some potential areas which need to be developed are coral reefs, unique fish species, vast and beautiful white sand beaches, natural fishing spots, snorkelling tourism, etc. Subsequently, tourists also enjoys underwater scenery and pre-historic objects namely planes and shipwrecks, as well as fish hunting (Fandeli and Mukhlison, 2000; Hall 2001). The economic condition of the community plays a crucial role in supporting or sustaining tourism development. It also has a positive effect on the local people and they tend to be hospitable. Therefore, a combination of social economy and excellent conditions produces an effective outcome. The main resources of marine tourism in the Spermode Archipelago are coral reefs, due to their unique attraction to the area. Spermode Archipelago is a group of small islands in the middle of the Indonesian archipelago. This archipelago has a unique ecosystem such as coral reefs and seagrass. In this archipelago, people live who are aware of the importance of their unique ecosystem as a tourist destination. This community-based Island is extremely potential for tourism development. Many small islands in Indonesia have unique socio-cultural conditions and beautiful natural resources but have not yet developed as tourist destinations. Development of tourist destinations will drive the small island economy so that will increase welfare of the coastal community. This study aims are (i) Determining the socio-economic conditions of small islands, especially the livelihoods and incomes of local communities. (ii) Determining condition of coastal and shallow marine resources around small islands in supporting the development of marine tourism in one of the small islands in Indonesia.

\section{Research Methods}

\section{Research Location}

The study was conducted in May-October 2019 on one of small island (Barrang Caddi Island) in Spermode Archipelago, South Sulawesi Province, Indonesia. Baring Caddie Island is located quite remote but not too far from the provincial capital of South Sulawesi. Barrang Caddi Island is located in the ordinate point $119^{\circ}, 19^{\prime}, 15^{\prime \prime} \mathrm{EL}$ and $05^{\circ}, 04^{\prime}, 50$ ” SL, Indonesia (Fig. 1).

\section{Collecting Data}

Data collection on environmental and marine resource conditions is carried out by, among others, (i) site observation, (ii) underwater survey by observing the condition of coral reefs. The collection of community socio-economic data was carried out by interviews and Focus Group Discussions. Our sample population is a collection of people who are at the study site who represent all the demographic structure of the sample. Total population sample is 50 persons. Existing representation includes age, gender, type of work, level of education, type of work and distribution of residence. Some sample populations were found to be distributed evenly and contained representation of each of the elements previously described. Before selecting the sample population in the survey, we included it in the sampling frame to maintain a scattered sample population and represent the sample. After the sample is taken, some information that does not meet representation requirements is removed, such as the wrong address mentioned, the wrong age, unsuitable work, or the population that is not a local resident. To maintain the truth of the results of the interview in the survey, we let them respond to the survey by clarifying the data we took. The response rate provided was very supportive of the validity of the information we got.

This primary data was collected in the following steps.

Fields observation. The fields observation is carried out on the condition of natural resources (beach), the cleanliness of the yard, the edge of the beach and the environment of public facilities, the completeness of supporting facilities and infrastructure and the arrangement of the road layout, general conditions, other actual conditions. Besides that, in the survey of environmental conditions, we also conduct a survey on the environment that is protected by the community as a conservation area. One of the resource requirements that can support the potential for tourism success is also a concern in our survey. In the survey we took some pictures and videos to strengthen the explanation of the information we got. The white sandy beach survey was the target of the survey. Besides that, the cleanliness of the environment of public facilities, the regulation of 
public areas. Specifically for the underwater survey, we collect data through photos and videos to analyze the condition of coral reefs, seagrass habitats and other underwater environmental conditions. This survey uses underwater equipment so we are able to get information at depths of up to $5 \mathrm{~m}$ below sea level.

Interviews. The interview was conducted on a sample of the population from the community living on Barrang Caddi Island. Barrang Caddi Island is one of the islands in Spermode archipegos. Interview was done to collecting information related economic, social and cultural conditions of the community. In interview, samples are the focal point of research must represent the target population and the information collected should represent true and good concepts. We carry out a standardized procedure in which the data we collect mostly represent the characteristics of the areas that our research targets. We ask the questions needed in during interview.

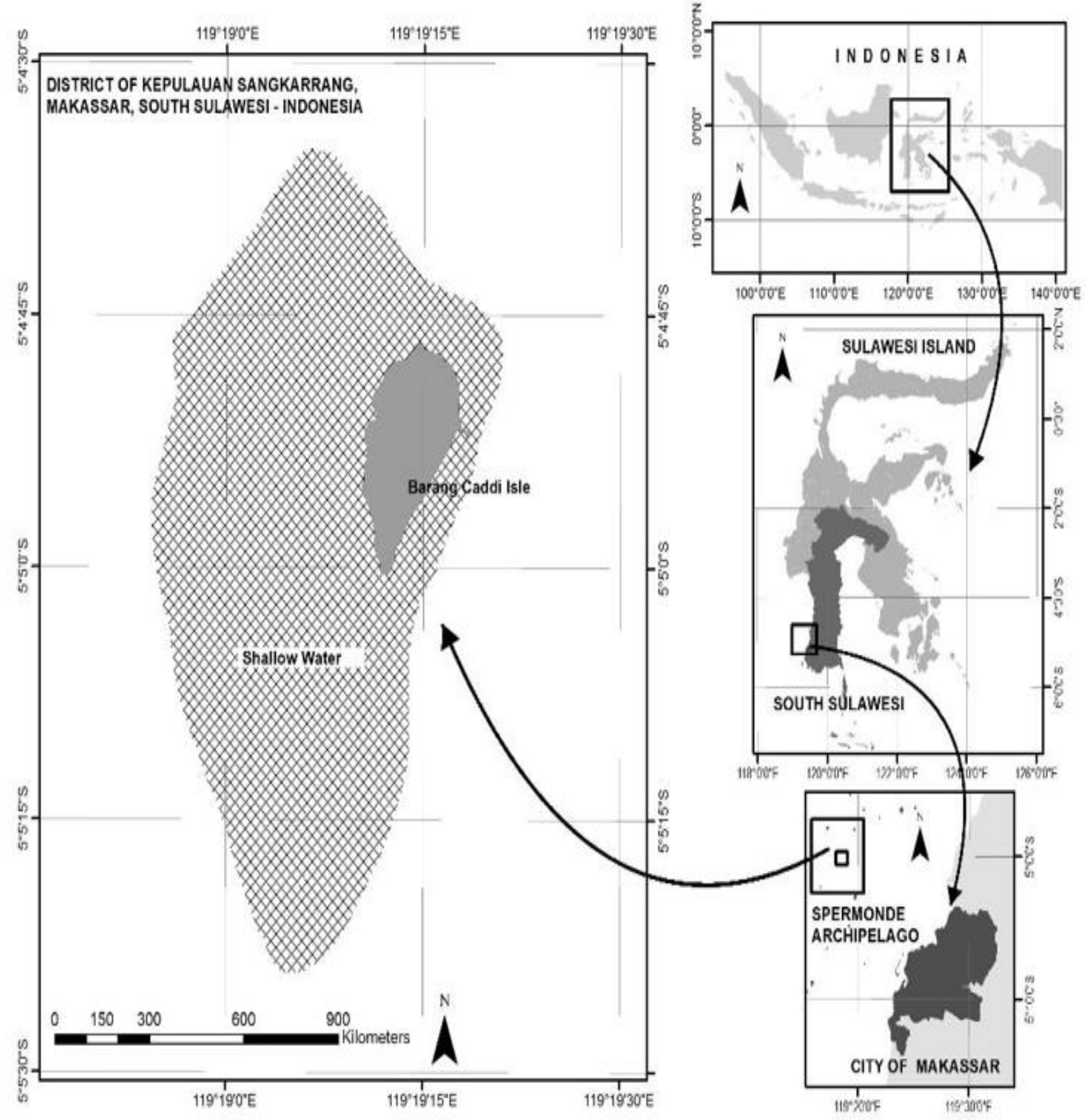

Fig. 1: Maps of study sites 
Focus Group Discussions (FGD). This FGD was carried out by involving village government officials, cultural and cultural leaders, community leaders, youth, students and parents of achievement from housewives, government employees, seaweed farmers, fishermen, private employees living in the research location. Before conducting the FGD, we provide a preliminary explanation in the form of a percentage in front of a population group that represents all components of society. Data collection consisted of a team of experts from the University. The research team conducting the discussion is experienced in the field of social research. This will facilitate the review of the questionnaire to avoid human error. When conducting FGD, we involve all the respondents' representatives and try to classify all the small groups that exist. After conducting interviews, we decided to take complete data by deep interviewing on several representative samples after 2-3 interviews. In this case, we are got 10 key respondents, with knowledge and experience who could represent other respondents. It is important to see the distribution of the representative population of the sample. The pattern of group discussion is open and all related to the existence and potential of the island for tourism development. We provide assistance and mediation in retrieving more relevant information. this effort illustrates some people who have the right competencies. Our documentation system is doing well. Besides that, we also try to group respondents into the appropriate groups. In each discussion, we make an introduction and marking types of information in general and specifically. Information collected, clarified and classified into specific themes in the form of economic studies, social studies of society and study of community culture. This pattern is carried out by means of group discussions and deepening in-depth interviews to get a more detailed and clearer picture of issues related to the research topic (Groves et al., 2004). In the process of gathering more detailed information we do with in-depth interviews. There were fewer respondents for interviews compared to the FGDs. It is well known that information gathering techniques are needed so that the results of the discussion are truly representative and illustrate the real socio-economic conditions of the community.

\section{Findings}

\section{Social and Economic Condition}

From the interview method, we found information that the main livelihood of local people, there are $42 \%$ of fishermen with small boats under 5 GT, while $40 \%$ are entrepreneurs and the rest of the respondents are civil servants, labor workers or employees and big boat owners (Fig. 2). Mapping of job description was carried out in the entire research location and this offers information on the average monthly income. It was discovered that $50 \%$ of the respondents earn between Rp1.000.000 (68\$) and Rp5.000.000 (340\$), while $18 \%$ earned below Rp1.000.000 (<68\$) and 8\% earned above Rp10.000.000 (>682\$) (Fig. 3).

The income range was obtained from the respondents within the age group of 20 - 60 years. However, only 4 people earned above Rp10.000.000 (>682\$), which means that there are well-established citizens (Fig. 4).

The local community has a traditional culture that is maintained such as dance, art and crafts, which are subsequently celebrated during traditional ceremonies. Dance and music are performed during wedding ceremonies. These activities are preserved and intensively revered whenever the need arises. During special events such as wedding ceremonies, the bride and groom parade around the village. This event is fascinating and is still being practiced, although it is unclear when it was first initiated. Other cultural events such as the traditional dance are still properly preserved, irrespective of the fact that it is rarely celebrated (Table 1).

The combination of people's income and culture is an interesting thing to say in this study. However, a very important supporting result is the condition of marine resources, especially coral reefs, which can be a special attraction for visitors. At the research location, it appears that marine resources have good availability.

\section{Marine Resources Status}

Through underwater observation method, many live coral reefs can be found around the island at depths greater than 1.5 meters, mostly hard and soft corals. Some underwater locations have small numbers of dead coral. The highest percentage of live coral cover is found on the northern side with hard coral cover. Expanses of coral reefs that are still in good conditions can be found south, west and northwest of the island, most of which are live hard corals. The dominant corals found were massive, digitate and foliose, soft corals and dead coral cover (Table 2).

Expanses of coral reefs that are still in good condition are found south, west and northwest of the island, mostly live hard corals. Furthermore, they are dominantly found in massive, digitate and foliose, soft and dead covers. 
The visitors prefer the north-western part of the Island for snorkeling and diving activities because there are hard and soft coral cover is found at a depth of 2 to $4 \mathrm{~m}$. One of the trending recreational activities in the sea is the feeding of a marine organism on woven bamboo. The visitors tend to be fortunate enough to witness the launching of the culture ceremony, The local peoples' routine activities are fascinating to watch and are developed into a recreational, cultural tour when properly packaged. There is potential activity that support local people involvement (Table 3).

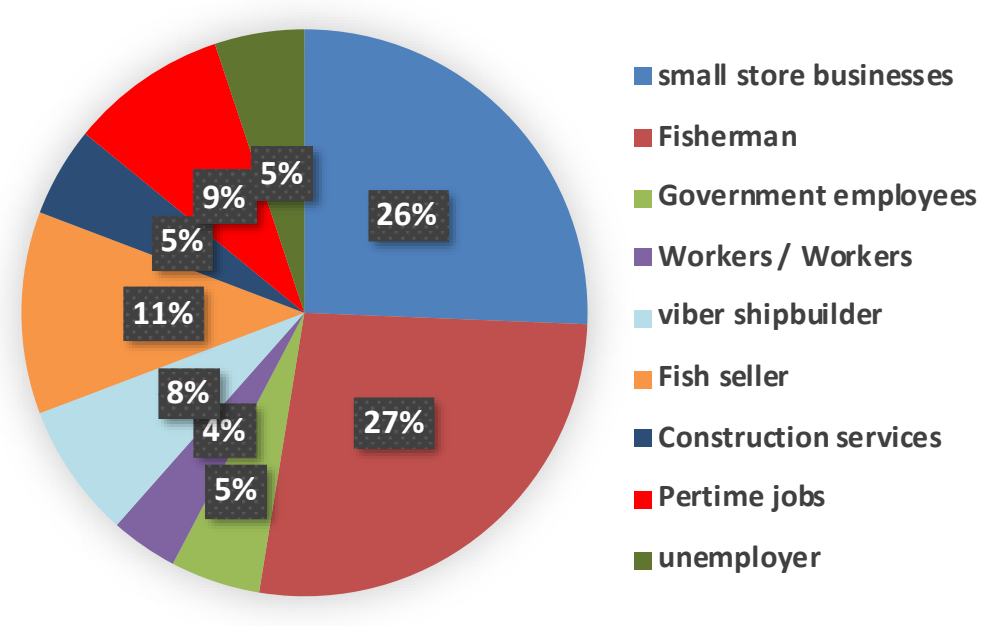

Fig. 2: Types of community work at study sites

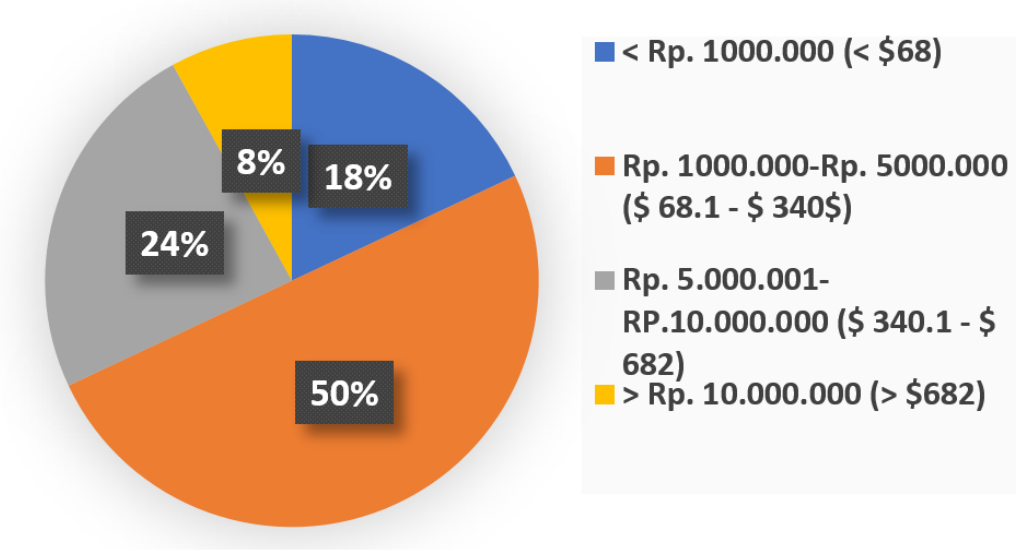

Fig. 3: Distribution of work income mapping for the community at the study site

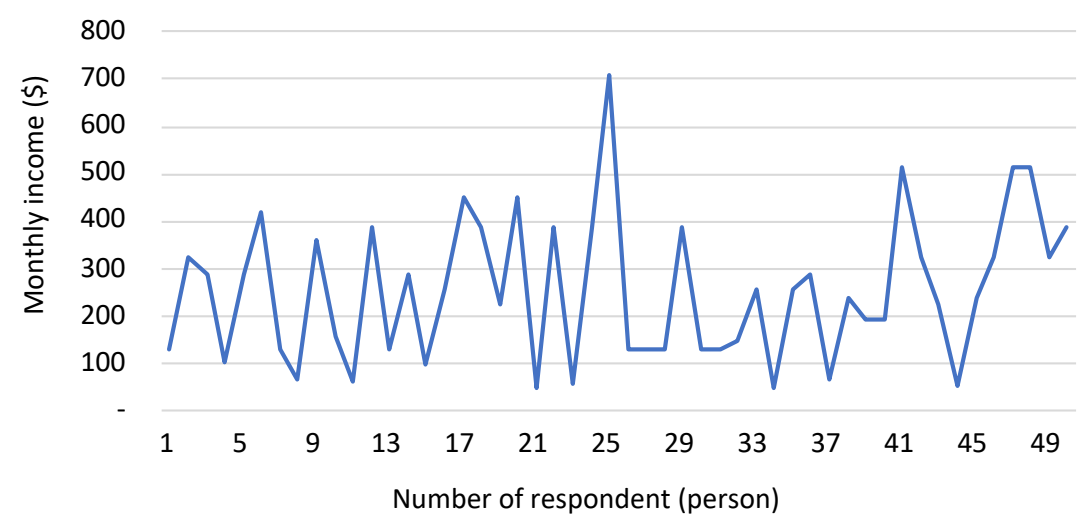

Fig. 4: Range of monthly income month at the study site 
Table 1: Information about culture around the research location

\begin{tabular}{|c|c|c|c|c|c|c|c|}
\hline \multirow[b]{2}{*}{ \# } & \multirow[b]{2}{*}{ Cultural event } & \multicolumn{2}{|c|}{ Preserved } & \multicolumn{2}{|c|}{ Still shown on the local village } & \multicolumn{2}{|c|}{ Shown once in a while } \\
\hline & & Yes & No & Yes & No & Yes & No \\
\hline 1 & Traditional dance & $\sqrt{ }$ & & & $\sqrt{ }$ & $\sqrt{ }$ & \\
\hline 2 & Local ceremony & & & & & $\sqrt{ }$ & \\
\hline 3 & Traditional customs & $\sqrt{ }$ & & & $\sqrt{ }$ & $\sqrt{ }$ & \\
\hline 4 & Religious event & $\sqrt{ }$ & & & $\sqrt{ }$ & & \\
\hline 5 & Other cultural ritual & $\sqrt{ }$ & & & $\sqrt{ }$ & $\sqrt{ }$ & \\
\hline
\end{tabular}

Table 2: Depth and dominant coral type around the research location

\begin{tabular}{llll}
\hline No & Position of coral reef & Dominant coral type & Depth (m) \\
\hline 1 & Southwest & Massive, Foliose, Branching & 4 \\
2 & North & Massive, digitate & 4 \\
3 & Northwest & Massive, digitate & 4 \\
4 & West & Massive, Foliose & 5 \\
\hline
\end{tabular}

Table 3: Potential activity and community-based tourism object in study sites

\begin{tabular}{|c|c|c|c|}
\hline No & Object & Tourims Activity & Local People Involvement \\
\hline 1 & Coral Reef & Diving, snorkeling & $\begin{array}{l}\text { Diving/snorkeling guide, boat rent, diving/snorkeling equipment } \\
\text { rent, underwater photography hiring }\end{array}$ \\
\hline 2 & $\begin{array}{l}\text { Karamba (Woven Bamboo) } \\
\text { and Fish Cultivation }\end{array}$ & $\begin{array}{l}\text { Fish feeding, } \\
\text { educational recreation }\end{array}$ & Fish food selling, boat rent, photographer, interpreter \\
\hline 3. & Culture & $\begin{array}{l}\text { Photography tourism, } \\
\text { culture interpretation }\end{array}$ & Tour guide \\
\hline 4 & Local People Lives & $\begin{array}{l}\text { Exploring the Island, } \\
\text { socializing with villagers }\end{array}$ & Tour guide, selling agricultural product, making souvenirs \\
\hline 5 . & Sunset & Sunbed ding/Karamba & Selling night lamp, selling snack, photographer. \\
\hline
\end{tabular}

\section{Discussion}

\section{Socio Economic Condition}

Barrang Caddi as one of the small islands in Indonesia which is located in the middle of the cluster of Indonesian islands. This island has a unique socio-economic community. The people who live on this island mostly can support tourism development. This can be seen from the good habits of the community. Communities like to work together and help each other for the benefit of their regional development. This kind of culture is very suitable for the development of tourism in an area. The development of tourism on a small island is one of the things that feels the need for community participation. Unique areas and habits of living together will be very helpful in designing sustainable marine tourism. Marine tourism is the only strength of the small island community. Community participation is the key to the success of this small island tourism development, especially to improve their economic, social and cultural sectors. The economic, social and cultural impact of community involvement in tourism management determines the success of community participation. Strong community participation encourages in helping to make sustainable tourism management policies. Of course, the motivation of the community is a determinant of the success of participation which is supported by policies and other factors (Masud et al., 2017). Research on the sustainability of coastal tourism that was carried out in Tanjug Kelayang, Belitung Island, Indonesia, gave the result that socio-economic activities supported by coastal tourism development planning policies became a very important factor for the success of coastal tourism development in this area (Hengky and Kikvidze, 2020).

The development of marine tourism, particularly in Small Island is one of the tools that strengthen the economy and is determined by several factors. Poor socioeconomic conditions lead to inadequate economic development. However, a properly established society integrates culture and economy. Cultural values are implemented to improve infrastructural development in regional areas (Kurniawan et al., 2016). The success of tourism management in coastal areas and archipelago is maintained by the active participation of the locals and fishermen (Dahl, 1997). One of the crucial factors that define the sustainability of development and infrastructure in coastal areas and archipelagoes is integrated management, particularly between the stakeholders, villagers and tourism organizers. This tends to reduce any potential conflict caused by the number of visitors and immigrants (Christie et al., 2003). Another special measure that needs to be applied is by involving all related parties influenced by the program's action and regulation. In addition, it is an efficient decision-making approach (Dahl, 1997). However, it is essential to observe the adversity involved in pursuing maximum scale economic improvement and profit, particularly in terms of 
business production. In our research location, communities have a good income range in the strata of the local economy as seen from the results of a survey that was conducted. This condition provides an opportunity for the development of a better economic power. Capital development activities that encourage tourism can also be a serious concern. The assumption is that the small capital spent by local people will also be able to spur travelers to spend their money on buying products produced by the community. Some regions with sufficiently strong capital can attract substantial profits. However, existing social capital is strong enough to encourage seriousness in maintaining an appropriate alternative source of income. Social capital that arises from local community is built up can be followed by significant economic benefits for the community. The advantage will still be obtained if the community really wants to maintain the continuity of their strength in developing the people's economy from marine tourism sources. Transportation also hampers the development of marine tourism in almost all archipelagic areas (Brookfield, 1990). Access to tourist areas is the main factor driving the number of visitors to a tourist area, then climatic conditions and local economic strength. In some developing areas, the stability of political conditions is also a determinant of the number of tourist visits (Opršal and Harmácek, 2018). A sustainable management system needs to be considered by thoroughly observing the physical support and social economy of the people (Wong, 1998; Ferreira and Perks, 2020). Moreover, unique historical heritage and societal culture are also a tourist attraction for both domestic and international visitors (Bjork, 2000). Bali Island tourism is a good example of the strength of local culture in supporting tourism development which has implications for the strength of the region to become a national and world tourist destination. However, this cultural strength has not yet fully received support from the rise of Bali Island tourism (Wibawa and Susanto, 2020). Interestingly, the successful development of archipelagos as a tourism destination is through the existence of the natural environment such as the condition of marine and coastal resources, peoples' welfare particularly the economy of the area, visitors' satisfaction level and active participation of the locals in maintaining the region which has become an asset worth preserving (Hamdiyah, 2004). Community based tourism is one of the efforts that strengthen peoples' participation because of the benefits it offers (Nugroho et al. 2020). Benefits are important, particularly in the developmental process of marine tourism. Eco-tourism areas are potential tourist destinations. Therefore, it is crucial to maintain its sustainability as well as the preservation of the oceanic environment to provide continuous economic benefits (López-Guzmán et al., 2011). However, this is based on several approaches such as minimum negative impact from visits, in addition to marine, natural, sustainable, cultural and historical tourism (Dowling, 1995). These strategic concepts are responsible for sustaining natural resources and offer economic benefits. It also maintains and preserves cultural integrity which is an added value that tends to increase the number of visitors. Tourism activities in marine environment aid in the conservation of nature and its authenticity and sustainability boosts the wealth of the locals (Cater and Lowman, 1994). Furthermore, an adequately packed tourism product relies on local facilities, conservation sites, eco-friendly destination and local resources (Cater and Lowman, 1994; Valentine, 1993). In relation to introducing small island tourism potential, promotion in various forms is very possible. One that has been done is on the island of Rote. Rote Island has a lot of uniqueness that has huge tourism potential. However, the magnitude of the tourism potential has not been fully utilized properly. To be able to develop tourism on this island, publication in the form of storytelling maps sourced from research results obtained from information from local community is very important to do. In addition, information dissemination in the form of storytelling maps also contains information about typical animals which are endemic animals. This pattern is one of the strategies to make tourist areas known and visited by visitors (Laksono et al., 2018).

\section{Marine Resource and impact on Economic Aspect}

Our research location in Barrang Caddi Island have beautiful natural resources conditions that support tourism development. The visitors prefer to visit the north-western part of the Island for snorkeling activities because there are hard and soft coral cover is found at a depth of 2 to $4 \mathrm{~m}$. One of the trending recreational activities in the sea is the feeding of a marine organism. It is carried out using woven bamboo baskets for shark and grouper cultivation in the north-western part of the Island. This type of community-based activity involves the owners of bamboo farms and craftsmen and this activity is usually conducted in the mornings and afternoons. An interesting spot to visit is the traditional boat construction yard in the western part of the island, or just sitting and enjoying the daily routine of the villagers. Overall, the condition of tourist destinations is quite good which includes attractions, amenities, accessibility, image, human resources and tourism prices. However, the attraction of tourists to visit is the main attraction for tourism activities in this area. Tourism supporting facilities and infrastructure have less value among other tourism supports. One of the factors that support the high tourist visits in this area is the condition of the coral reefs which are quite good, underwater visibility, beach conditions with white sand and biodiversity (Kristianto et al., 2019). The potential of underwater resources in this area can be developed and enjoyed with underwater views with various tools including snorkeling, diving, swimming, sunbathing, or other activities such as hiking, fishing, joining fishermen, cooking, eating, etc. (Effendi et al., 2019). Natural resources are assets; however, efforts to sustain them aid 
in boosting the economy and maximize the welfare of the locals. Small island particular in our study sites mostly has great resources, namely coral reefs and white sand beaches. Holistic and integrated management supports the sustainability of this area as a potential tourism destination. It is essential to have an in-depth knowledge of the social, economic and cultural dimensions as well as natural resources such as coral reef in archipelagic sites. This is because tourism development is in accordance with natural resources. Therefore, the formula for its management is one of the marine tourism powers that need to be considered as well as the social, economic and cultural aspect of the people (Adrianto, 2006). Moreover, marine tourism is heavily dependent on any location with adequate natural resources and the existence of biota in the area. Their activity relies on the coral reef and provides opportunities for snorkeling and diving. The condition of the coral reef is important because this potential is the main attraction for tourists and visitors interested in carrying out diving tour in vast oceanic areas. The number of visitors also corresponds to their desires to observe and examine the coral reefs.

The natural resources that are maintained in study sites are one of the triggers for tourists to visit. Cover of coral reefs that are still in a very good range in several locations become a strong capital in spurring the arrival of tourists. However, currently, conservation activities are guarantees for the sustainability of natural resources, especially coral reefs. Local people often catch lobsters that are around their sea area. They then sell lobsters as a source of income. Unfortunately, the number of lobsters that are already fewer. A good strategic issue in maintaining the sustainability of resources such as coral and lobster on this island is sea tourism. Underwater tourism is an ecotourism that is highly recommended in several tourism industries. However, tourists must be very disciplined to do environmentally friendly activities. The fact that occurs in several locations, the power to protect the environment with marine tourism activities is still an interesting discussion. Some management policies conflict with the desire of tourists to enjoy more available natural resources. Not a few of the tourists actually go out of control and have an impact on the damage. Good rules of the game should be able to be obeyed by visitors and managers to be able to realize good ecotourism in this area. Success that occurs with the sustainability of marine resource management can spur economic success of local communities. Some coral reefs that are still awake on the west side of Barring Lompo Island are a form of seriousness to maintain the coral reef resources as one of the drivers of ecotourism success in this region. A certain case study conducted in Palawan Island, Philippines, shows that the people actively participated in tourism development. They also play an important role in traditional events by initiating community-based marine eco-tourism. Okazaki (2008) reported that this effort is an essential aspect of the successful development of tourism in the area. Economic power serves as the principal tools that contribute immensely to the development of marine tourism in archipelagic areas (Fandeli and Mukhlison, 2000). Subsequently, it relies on the natural environment and social culture reinforcement which is consistently improved by the locals contributes to the development of the region (Bjork, 2000; Dowling, 1995). It also strengthens the peoples' alignment in preserving the local tradition, which supports sustainable environmental protection and management (Masberg and Morales, 1999).

Consequently, marine tourism in study sites embraces certain concepts based on economy empowerment in order to guarantee the management of natural resources. Additionally, visitors are expected to support and improve the economy as well as appreciate the peoples' culture. Generally, sustainable tourism management, which relies on the economy, cultural and social aspect of the people, guarantees continuous benefit in the future (Davis and Tisdell, 1996). Nature tourism is essentially how the locals take advantage of the area without destroying or reducing the quality of the environment as well as their social, economic and cultural aspects (Zhiyong and Sheng, 2009). The paradigm of solving and restricting tourism development effort, which tends to destroy the environment, needs to be maintained continuously. Local community, culture and environmental sustainability, quality of resources and tourist destination are crucial components which need to be conserved through harmonious effort (McCool and Lime, 2001). Support from related parties concerning the sustainability of marine tourism which reduces conflict between stakeholders (such as fishermen, marine tourism committee, scientist and researcher, government officer, NGO and conservationist) needs to be proactively conducted (Christie et al., 2003). The involvement of all components managing the area is reinforced by the culture of the people; additionally, this relates to their social and economic conditions. Stakeholders play a major role in tourism development as well as prioritizing and offering insight about the peoples' participation which is improved by the surrounding natural environment. The success of tourism activity in this area is highly influenced by community-based strategies consistently integrated to support and provide opportunities, including boosting the economy and social culture life of the people (Harris, 2009). Several important points in supporting the success of tourism development are organizational capabilities, sufficient resources. as a regulatory measure it is also based on several aspects, including strategic leadership, internal management, networks and relationships, infrastructure management and financial management (Kajornbun and Dhirathiti, 2019). Economic power serves as the principal tools that contribute immensely to the 
development of marine tourism in archipelagic areas (Fandeli and Mukhlison, 2000). Subsequently, it relies on the natural environment and social culture reinforcement which is consistently improved by the locals contributes to the development of the region (Bjork, 2000; Dowling, 1995). It also strengthens the peoples' alignment in preserving the local tradition, which supports sustainable environmental protection and management (Masberg and Morales, 1999).

\section{Conclusion}

A small island is a unique environment with different regions depending on the cultural life of the local community. A small island such as Barrang Caddi is an example of an island with good economic conditions. This picture of economic conditions can be improved by developing tourism activities. Tourism is a source of income for the community by selling various fishery and handicraft products. This island needs serious handling to be developed to become a tourist destination and with the involvement of the community to be able to increase people's income. Some of the actions to increase visitors are by keeping the beaches clean, maintaining marine resources beautiful and sustainable. The condition of coral reefs and marine resources that are maintained will be very good in managing marine tourism. The combination of socioeconomic community and potential marine resources in small island supports the preparation of communitybased tourism destination.

\section{Acknowledgement}

We are grateful to the Ministry of Research and Technology of the Republic Indonesia, for the full research funding of this research project. Our gratitude goes to the Fishery Laboratory staff, Faculty of Fishery and Marine Science Halu Oleo University for their assistance in the sample analysis. Thanks for LPPM UHO for facilitation of the grant.

\section{Funding Information}

This research funding by Ministry of Research and Technology of the Republic Indonesia.

\section{Author's Contributions}

Ma'ruf Kasim: Original draft preparation, research investigation, conceptualization, methodology, draft manuscript.

Dedy Oetama: Investigation, research investigation, methodology, manuscript.

Ahmad Bahar: Writing-review and editing, formal analysis, conceptualization.
Mareyke Alelo: Formal analysis, research investigation, conceptualization, methodology.

Kartika Kusuma Wardani: Research investigation, conceptualization, methodology.

Hertina Susandari: Research investigation, conceptualization, methodology.

\section{Ethics}

Each author has agreed to publish this manuscript and will be responsible for all issues that arise in connection with the publication of this manuscript.

\section{References}

Adrianto, L., (2006). Synopsis Introduction to the Concept and Methodology of Economic Evaluation of Coastal and Marine Resources. Center for Coastal and Ocean Resource Study. IPB. Bogor. http://pkspl.ipb.ac.id/download/file/valuasi_ekonom i.pdf

Asker, S. A., Boronyak, L. J., Carrard, N. R., \& Paddon, M. (2010). Effective community based tourism: A best practice manual.

https://opus.cloud.lib.uts.edu.au/bitstream/10453/35 150/1/askeretal2010effectivecbt.pdf

Aspiany, Sutrisno Anggoro, S., Purwanti, F., Bambang, I., Gunawan (2019). Strategies for sustainable ecotourism development in the marine waters of Bontang City, Indonesia. AACL Bioflux 12(5):1779-1787.

Bjork, P. (2000). Ecotourism from a conceptual perspective, an extended definition of a unique tourism form. International journal of tourism research, 2(3), 189-202.

https://onlinelibrary.wiley.com/doi/abs/10.1002/(SI

CI)1522-1970(200005/06)2:3\%3C189::AID-

JTR195\%3E3.0.CO;2-T

Brookfield, H.C. (1990) 'An Approach to Islands' in W. Beller, P. d'Ayala \& P. Hein (eds.) Sustainable Development and Environmental Management of Small Islands, UNESCO-Parthenon, Paris, pp. 23-33. https://digitallibrary.un.org/record/194621

Cater, E., \& Lowman, G. (1994). Ecotourism: A Sustainable Option?. Wiley. 230p. ISBN-10: 978-0-471-94896-4. https://www.wiley.com/en$\mathrm{id} /$ Ecotourism $\% 3 \mathrm{~A}+\mathrm{A}+$ Sustainable+Option\%3F-p9780471948964

Christie, P., Makapedua, D., Lalamentik, L.T.X. (2003) Bio-physical impacts and links to integrated coastal management sustainability in Bunaken National Park, Indonesia. Indonesian J Coast Mar Resources, Special Edition, No. 1, 1-22. 
Dahl, C. (1997). Integrated coastal resources management and community participation in a small island setting. Ocean \& Coastal Management, 36(1-3), 23-45. doi.org/10.1016/S0964-5691(97)00018-5

Davis, D., \& Tisdell, C. (1996). Economic management of recreational scuba diving and the environment. Journal of environmental management, 48(3), 229-248. https://doi.org/10.1006/jema.1996.0075

Dowling, R. K. (1995). Ecotourism: concept design and strategy. Tourism Recreation Research, 20(1), 60-61. https://www.tandfonline.com/doi/pdf/10.1080/0250 8281.1995.11014739

Effendi, I., E Elizal, E., \& Jupendri, J. (2019). Identification of marine ecotourism objects on Pulau Jemur,Riau Province, Indonesia. IOP Conf. Series: Earth and Environmental Science 348. 012032. doi:10.1088/1755-1315/348/1/012032

Fandeli, C., \& Mukhlison. (2000). Pengusahaan Ekowisata (C. Fandeli, Ed.). Fakultas Kehutanan Gadjah Mada University Yogyakarta.

https://opac.perpusnas.go.id/DetailOpac.aspx?id= 504533\#

Ferreira, D., \& Perks, S. (2020). Dimensional framework of tourism indicators influencing destination competitiveness. African Journal of Hospitality, Tourism and Leisure, 9(3), 1-21. https://ouci.dntb.gov.ua/en/works/4L8ByMv4/

Groves, R. M., Fowler, F. J., Couper, M. P., Lepkowski, J. M., Singer, E., \& Tourangeau, R. (2004). Survey methodology. Hoboken, NJ: Wiley. 463p.

Hall, C. M. (2001). Trends in ocean and coastal tourism: the end of the last frontier?. Ocean \& coastal management, 44(9-10), 601-618. doi.org/10.1016/S0964-5691(01)00071-0

Hamdiyah, S. (2004). Study of Suitability and Development of Marine Tourism in Abang Islands, Batam City. Thesis. Graduate School. IPB University. Bogor.

https://repository.ipb.ac.id/handle/123456789/41472

Harris, R. W. (2009). Tourism in Bario, Sarawak, Malaysia: A case study of pro-poor community-based tourism integrated into community development. Asia Pacific Journal of Tourism Research, 14(2), 125-135.

https://www.tandfonline.com/doi/abs/10.1080/1094 1660902847179

Hausler, N., \& Strasdas, W. (2003). Training Manual For Community-based Tourism, Zschortau: Inwent. https://www.scribd.com/document/117900601/Ecot ourismTrainingManual-Cbt

Hengky, S.H., \& Kikvidze, Z., 2020. Sustainable Coastal Tourism in Tanjung Kelayang, Indonesia, Tourism Planning \& Development, 18:3, 365-370, doi.org/10.1080/21568316.2020.1763444
Kajornbun, S., \& Dhirathiti, N. S. (2019). Local administration organisation capacity development for tourism promotion in the Andaman coastal provinces, Thailand. International Journal of Tourism Policy, 9(4), 300-319.

https://www.inderscienceonline.com/doi/abs/10.150 4/IJTP.2019.105494

Kurniawan, F., Adrianto, L., Bengen, D.G., \& Prasetyo, L.B. (2016). Vulnerability assessment of small islands to tourism: The case of the Marine Tourism Park of the Gili Matra Islands, Indonesia. Global Ecology and Conservation. 6, 308-326. doi.org/10.1016/j.gecco.2016.04.001

Kristianto, B., Fahrudin, A., \& Salim, Z. (2019, March). Determinants of sustainable small islands tourism management: Case study of Pahawang Island, Indonesia. In IOP Conference Series: Earth and Environmental Science (Vol. 241, No. 1, p. 012015). IOP Publishing.

https://iopscience.iop.org/article/10.1088/17551315/241/1/012015/meta

Laksono, D., Julzarika, A, Subehi, L., Hanhan A. Sofiyuddin, A.H., Dewi, K.E., Kayat, \& Isma M.F.N. (2018). Expedition Oe: A Visual-storytelling map on Rote Island's Lakes. Journal of Geospatial Information Science and Engineering. Vol. 1 No. 2. 87-93. https://doi.org/10.22146/jgise.40861

López-Guzmán, T., Sánchez-Cañizares, S., \& Pavón, V. (2011). Community-based tourism in developing countries: A case study. Tourismos, 6(1).

http://www.chios.aegean.gr/tourism/VOLUME_6_N o1_art04.pdf?origin=p

Masberg, B. A., \& Morales, N. (1999). A case analysis of strategies in ecotourism development. Aquatic Ecosystem Health \& Management, 2(3), 289-300. https://www.tandfonline.com/doi/abs/10.1080/1463 4989908656965

Masud, M. M., Aldakhil, A. M., Nassani, A. A., \& Azam, M. N. (2017). Community-based ecotourism management for sustainable development of marine protected areas in Malaysia. Ocean \& Coastal Management, 136, 104-112.

doi.org/10.1016/j.ocecoaman.2016.11.023

McCool, S. F., \& Lime, D. W. (2001). Tourism carrying capacity: tempting fantasy or useful reality?. Journal of sustainable tourism, 9(5), 372-388. https://www.tandfonline.com/doi/abs/10.1080/0966 9580108667409

Nguyen, T. B. T., Chau, N. T., \& Vo, L. X. S. (2018). Applying network analysis in assessing stakeholders' collaboration for sustainable tourism development: a case study at Danang, Vietnam. International Journal of Tourism Policy, 8(3), 244-270.

https://www.inderscienceonline.com/doi/abs/10.150 4/IJTP.2018.094502 
Nugroho, D. S., Hermawan, H., Putri, E. D. H., \& Mayasari, C. U. (2020). Community participation tourist attraction development in Jabal Kelor-a case study. OSF Preprints, 23.

Okazaki, E. (2008). A community-based tourism model: Its conception and use. Journal of sustainable tourism, 16(5), 511-529.

https://www.tandfonline.com/doi/abs/10.1080/0966 9580802159594

Opršal. Z., \& Harmácek, J. (2018). Geografické, Environmentální A Socioekonomické Determinanty Cestovního Ruchu V Malých Ostrovních Rozvojových Státech (Sids) (SIDS). Geografický C̆asopis / Geographical Journal 70(2), 161-177. ISSN 0016-7193. https://doi.org/10.31577/geogrcas.2018.70.2.09

Tasci, A. D., Semrad, K. J., \& Yilmaz, S. S. (2013). Community basted tourism: Finding the equilibrium in the COMCEC context.

https://stars.library.ucf.edu/rosenscholar/261/
Valentine, P. S. (1993). Ecotourism and nature conservation: A definition with some recent developments in Micronesia. Tourism management, 14(2), 107-115. doi.org/10.1016/0261-5177(93)90043-K

Wibawa, K. C. S., \& Susanto, S. N. (2020). Establishing a special autonomy model in Bali as a means of preserving hindu balinese culture and space. International Journal Of Scientific \& Technology Research 9(4):1609-1614.

Wong, P. P. (1998). Coastal tourism development in Southeast Asia: Relevance and lessons for coastal zone management. Ocean \& Coastal Management, 38(2), 89-109. doi.org/10.1016/S0964-5691(97)00066-5

Zhiyong, F., \& Sheng, Z. (2009). Research on psychological carrying capacity of tourism destination. Chinese Journal of Population Resources and Environment, 7(1), 47-50. https://www.tandfonline.com/doi/abs/10.1080/1004 2857.2009.10684909 